\title{
ROLE OF THE MAXILLARY TUBEROSITY IN PERIODONTOLOGY AND IMPLANT DENTISTRY-A REVIEW
}

\author{
Nicholas Montanaro ${ }^{1 \mathrm{a}}$, José Carlos Martins da Rosa ${ }^{2 \mathrm{~b}}$, Luis Antonio Violin Pereira ${ }^{3 \mathrm{c}}$, Georgios E. Romanos ${ }^{1 \mathrm{~d}^{*}}$ (i)
}

'Department of Periodontology, School of Dental Medicine, Stony Brook University, Stony Brook, NY, USA

2Department of Implantology, São Leopoldo Mandic Dental Research Center, Campinas ( SP), Brazil

${ }^{3}$ Department of Biochemistry and Tissue Biology, Institute of Biology, State University of Campinas, Campinas (SP), Brazil

${ }^{\mathrm{a} D D S}$

${ }^{b} D D S, M s C$, PhD

MDD, PhD

${ }^{d} D D S$, PhD, Prof, Dr med dent

\section{ABSTRACT DOI: https://doi.org/10.25241/stomaeduj.2019.6(4).art.5}

Background:The maxillary tuberosity in implant dentistry presents the clinical location for clinicians with respect to the periodontal, surgical, prosthetic, implantological and mechanical aspects.

Objective: The aim of this paper was to evaluate the role of the maxillary tuberosity based on the literature and to enhance the role of tilted implants placed in the maxillary tuberosity as an anchorage to the most posterior end of prostheses in order to avoid biomechanical complications from distal cantilevers.

Data Sources: Information was obtained mainly from the PubMed and MEDLINE databases, online books managed by the National Center for Biotechnology Information, and non-indexed sources. Previous studies have demonstrated more than $94 \%$ survival rates of implants placed in the maxillary tuberosity despite the usage of varied implant designs and surgical protocols. Data Extraction and Synthesis: The web search included the following keywords: bone, dental implant, dental implantation, maxillary osteotomy, osseointegration for period 1980 to 2017. Proper insertion of tapered implants with adequate bone condensation of the local cancellous bone is effective in generating the required primary stability and eventual osseointegration required for long-term success. In cases where implant placement in the maxillary tuberosity provides no immediate restorative benefit, various hard and soft tissues of the region can be harvested for autogenous grafting to address distant constraints. Usage of the maxillary tuberosity for implant placement or as a grafting source can provide increased options for clinicians to restore a patient's dentition to a higher quality without the requirement of more numerous, costlier and complicated surgical restorative procedures.

Keywords: Bone; Dental Implant; Dental Implantation; Maxillary Osteotomy; Osseointegration.

\section{Introduction}

The maxillary tuberosity (MT) is a bony region located bilaterally on the upper jaw that is posterior to the most distal molar roots. It is often characterized by its prominent rounded appearance that bulges outward from the face of the maxillary bones around the maxillary sinus. The tuber region is comprised primarily of spongy cancellous osseous tissue - specifically categorized as a combination of type III and IV bone with abundant marrow [1,2]. It is situated along the medial side of the pyramidal process of the palatine bone and forms an articular surface at this site. The posterior superior alveolar nerves and vessels pierce through the posterior surface of the MT, and this tu-

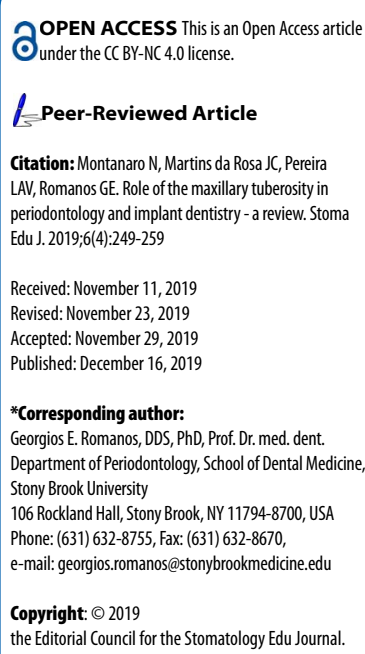

ber region also functions as an attachment point for the medial pterygoid muscles. In the past, soft and hard tissues of the MT served as excellent donor sites when these tissues were deficient elsewhere in the maxilla. It has been shown that gingival connective tissues can be harvested and grafted successfully at recipient sites for cosmetic and functional root coverage in the anterior maxilla $[3,4]$. The MT can also function as a bone source as there is frequently an abundance of untapped usable bone mass, even in patients with bone recession throughout the remainder of the maxilla. Bone harvested from the maxillary tuberosity has been used in the reconstruction of compromised sockets for immediate implantation, 


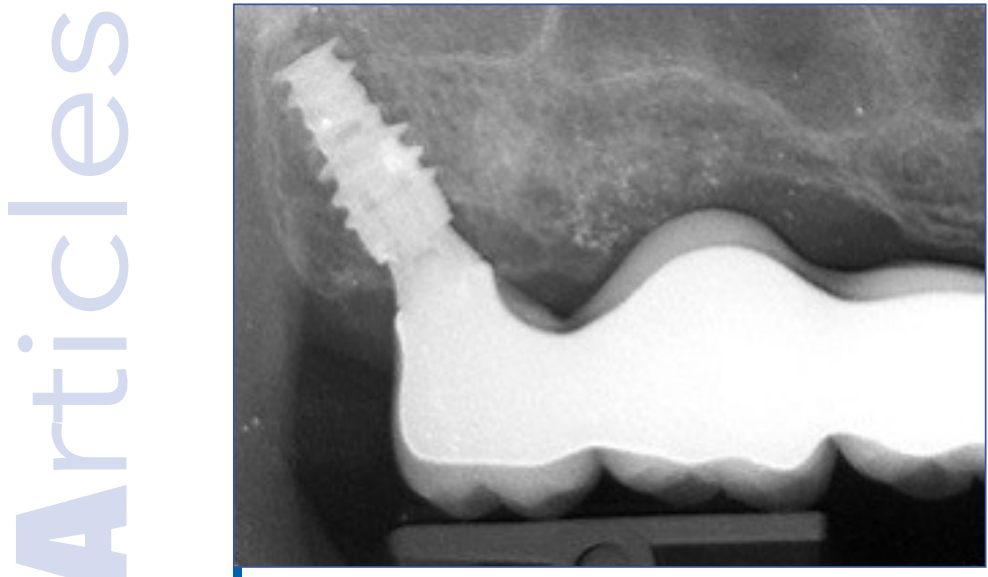

Figure 1. Maxillary tuberosity providing support for an implant-supported fixed prosthesis (courtesy: Dr. E. El-Haddad, Torino, Italy).

as well as effectively in the management of intrabony defects in mandibular molars [4,5]. Varying defects covering trauma, infection, or bone recession often result in structure changes of alveolar processes that cannot be candidates for implantation without additional grafting procedures. The usage of bone grafts harvested from the MT can provide a superb alternative source of autogenous bone to augment the alveolar ridges and sockets without the need for more invasive surgical harvesting procedures, such as when bone tissues are taken from the chin or the ramus [6]. Although the maxillary tuberosity does not naturally support teeth nor is it a traditional site for dental implants, it can provide support for some restorations in particular cases. The MT is a more permanent structure, and even with the extraction of all maxillary teeth, the MT remains with only minor resorption. It is speculated that the pterygoid medialis muscle provides loading forces during mastication which counteract disuse atrophy $[1,2]$. Bone resorption in the palatal direction and narrowing of the MT is generally only seen when tooth loss is secondary to pronounced periodontal disease. As such, the convex anatomy of MT should always be taken into consideration in traditional denture design as the medial and lateral walls resist the horizontal and torqueing forces which would move the denture base in the lateral or palatal directions [7-11]. In more recent times, the MT has been deemed as an acceptable site for implant placement, especially in cases where there is a need to avoid sinus grafting, thus providing increased stability for fixed (Fig. 1) or removable prostheses (Fig. 2). Implant placement in this posterior region is quite comparable to that of conventional implant placement elsewhere in the maxilla with only slight alterations of drilling, bone condensation procedures, and instruments in order to protect the weaker bone in the area. Several previous studies have demonstrated excellent survival rates comparable to that of implants placed throughout the remainder of the maxilla [12-21]. Successfully placed and osseointegrated implants in the tuber region can be used as abutments for implant-supported prostheses to avoid distal canti- levers and control bending moments in the posterior segments. Implant placement in the MT is a much more conservative option in treatment when there is insufficient bone mass throughout the rest of the maxilla. This allows for the circumvention of extensive surgical grafting or sinus lifting procedures that entail greater risk of complications. Implant placement in the MT becomes a more sensible choice for elderly patients, those with healing deficiencies, or those where cost for treatment is restricted.

The objective of this study was to evaluate the literature presenting implants placed in the MT region and the outcomes of the treatment and to discuss the clinical potential of this anatomical area as a donor site for soft and hard tissue in order to demonstrate the role of the tuberosity in periodontology and implant dentistry.

\section{Materials and methods}

This literature review was carried out through the utilization of PubMed.gov, an online database comprised of biomedical literature from MEDLINE, life science journals, and online books managed by the National Center for Biotechnology Information. Search criteria for scientific papers in this review were confined to the role of the maxillary tuberosity and pterygoid in implant dentistry.

This included anatomy, implant placement, removal of tissues, and surgical outcomes.

\section{Results}

A PubMed search was performed with the search criteria "maxillary tuberosity and implants", or "pterygoid and implants". This resulted in a total of 73 and 75 articles, respectively (148 total). Articles discussing use of non-dental implants in the tuberosity or pterygoid regions, or dental implants used for prostheses that do not ultimately restore teeth were excluded from our review. After exclusion criteria were applied and papers of insufficient data were removed from review, there were 10 papers of sufficient quality in which our study was based (Table 1). The tuberosity currently serves as an underutilized region of the maxilla that has the potential to be a critical area for implant placement in patients with bone deficiencies throughout the mouth. Despite its advantages, implant placement in this region is often hindered by its own anatomy; primarily the spongy bone of the maxilla is softer and more cancellous than that of the mandible, and bone density decreases posteriorly. The bone of the tuberosity contains high amount of bone marrow $[1,2,12,22,23]$. As such, any clinician planning for the placement of implants in this location must first take into consideration the relative lower density and properties of this osseous tissue to best avoid implant failure $[8,9,11,18,24]$. Generally, implants must be angulated to properly fit the tube-rosity bone structure with sufficient length. Angled (tilted) implants were seen as unfavorable to support large restorations in the past as they were 
Table 1. Survival rates of implants placed in the maxillary tuberosity across published studies[12-21].

\begin{tabular}{|c|c|c|c|c|c|c|c|c|c|c|c|}
\hline 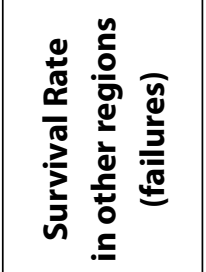 & ○े & $\begin{array}{l}\Xi \\
80 \\
0 \\
0 \\
0\end{array}$ & ○े & $\begin{array}{l}\bar{\Xi} \\
\text { ठें }\end{array}$ & ஓे & $\underset{z}{z}$ & 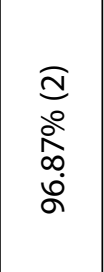 & 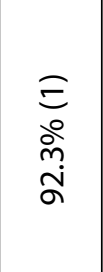 & $\frac{\Sigma}{z}$ & 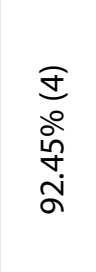 & 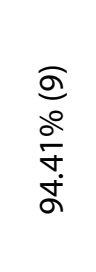 \\
\hline 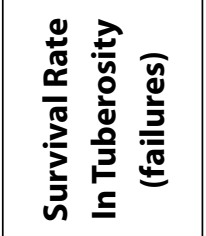 & ঃे & ஓे & ঃे & 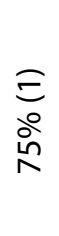 & ঃి & ঃे & ঃे & ஜे & $\begin{array}{l}\sqrt{n} \\
\stackrel{\circ}{0} \\
\text { à }\end{array}$ & 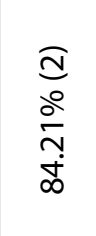 & $\begin{array}{l}\frac{\alpha}{m} \\
\hat{o} \\
\stackrel{\alpha}{\alpha}\end{array}$ \\
\hline 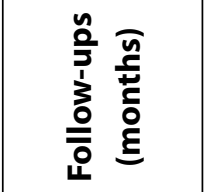 & $\stackrel{ \pm}{\sim}$ & $\stackrel{d}{\sim}$ & $\stackrel{m}{m}$ & $\stackrel{\infty}{-}$ & $\$$ & $\begin{array}{l}\stackrel{ \pm}{\infty} \\
\stackrel{0}{ } \\
\stackrel{\sim}{\simeq}\end{array}$ & 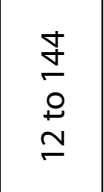 & $\begin{array}{l}\stackrel{\infty}{+} \\
\stackrel{0}{0} \\
\stackrel{0}{0}\end{array}$ & $\stackrel{+}{\sim}$ & $\begin{array}{l}8 \\
\stackrel{0}{0} \\
\stackrel{0}{0}\end{array}$ & 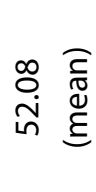 \\
\hline 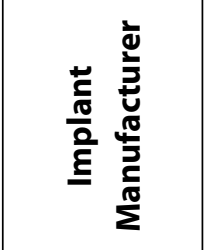 & 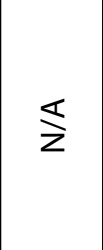 & $\frac{\mathbb{z}}{z}$ & $\frac{\Sigma}{z}$ & $\underset{z}{z}$ & $\frac{\Sigma}{z}$ & $\sum_{\mathcal{U}}$ & 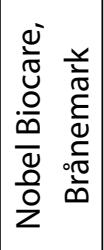 & 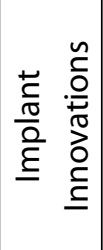 & 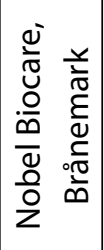 & 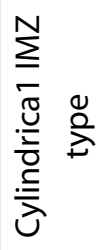 & \\
\hline 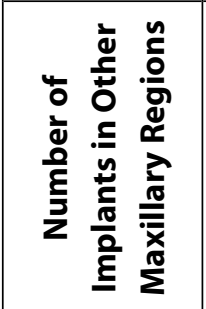 & $\nabla$ & $m$ & 0 & $N$ & 0 & $\stackrel{ }{\circ}$ & ఫ & $\stackrel{m}{-}$ & 0 & nn & $\bar{\sigma}$ \\
\hline 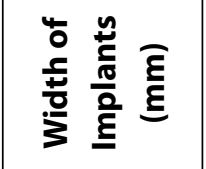 & $\stackrel{\circ}{+}$ & 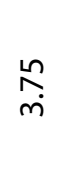 & \begin{tabular}{l}
$\infty$ \\
$\stackrel{+}{+}$ \\
$\infty$ \\
\hdashline$\dot{+}$
\end{tabular} & 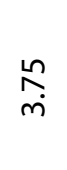 & $\$$ & $\begin{array}{l}\stackrel{\circ}{+} \\
\stackrel{+}{N} \\
\hat{m}\end{array}$ & $\begin{array}{l}\stackrel{\circ}{+} \\
\stackrel{\leftrightarrow}{N} \\
\stackrel{m}{m}\end{array}$ & $\begin{array}{l}\stackrel{\circ}{+} \\
\stackrel{+}{N} \\
\hat{m}\end{array}$ & 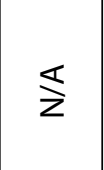 & 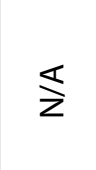 & \\
\hline 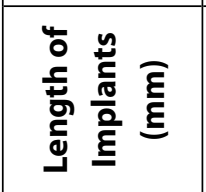 & $\stackrel{\circ}{\circ}$ & $\begin{array}{l}\stackrel{0}{m} \\
\frac{m}{\infty} \\
0 \\
\dot{0}\end{array}$ & $\stackrel{\circ}{\stackrel{+}{ \pm}}$ & $\begin{array}{l}\circ \\
\dot{m} \\
\infty \\
0 \\
0 \\
\dot{0}\end{array}$ & $\$$ & $\frac{\stackrel{n}{n}}{\stackrel{n}{\check{n}}}$ & $\begin{array}{l}\stackrel{0}{\dot{0}} \\
\text { ò } \\
\dot{m}\end{array}$ & $\begin{array}{l}0 \\
\grave{0} \\
o \\
0 \\
0\end{array}$ & 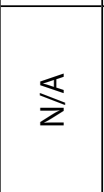 & $\frac{\Sigma}{z}$ & \\
\hline 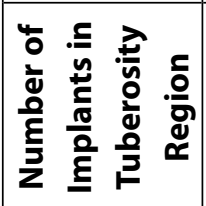 & $\sim$ & $N$ & $\sim$ & $\nabla$ & $N$ & $\lambda$ & $\approx$ & શิ & $\stackrel{N}{N}$ & $\stackrel{9}{-}$ & $\underset{\sigma}{\sigma}$ \\
\hline 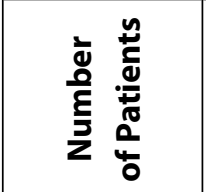 & - & - & - & - & - & $\wedge$ & $\stackrel{N}{ }$ & 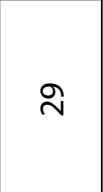 & ஜ & $\mp$ & $\underline{E}$ \\
\hline & 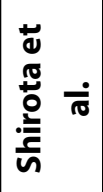 & $\begin{array}{l}\dot{\sigma} \\
\stackrel{0}{d} \\
\tilde{y} \\
\frac{\tilde{U}}{\tilde{J}}\end{array}$ & 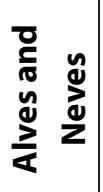 & 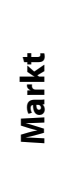 & 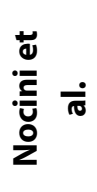 & 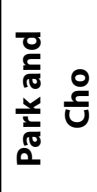 & $\begin{array}{l}\frac{\dot{\pi}}{0} \\
\frac{0}{\overline{0}} \\
\frac{0}{\alpha}\end{array}$ & 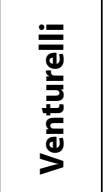 & $\begin{array}{l}\frac{\pi}{0} \\
\frac{\pi}{10} \\
\infty\end{array}$ & 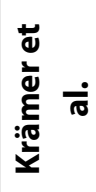 & 店 \\
\hline
\end{tabular}



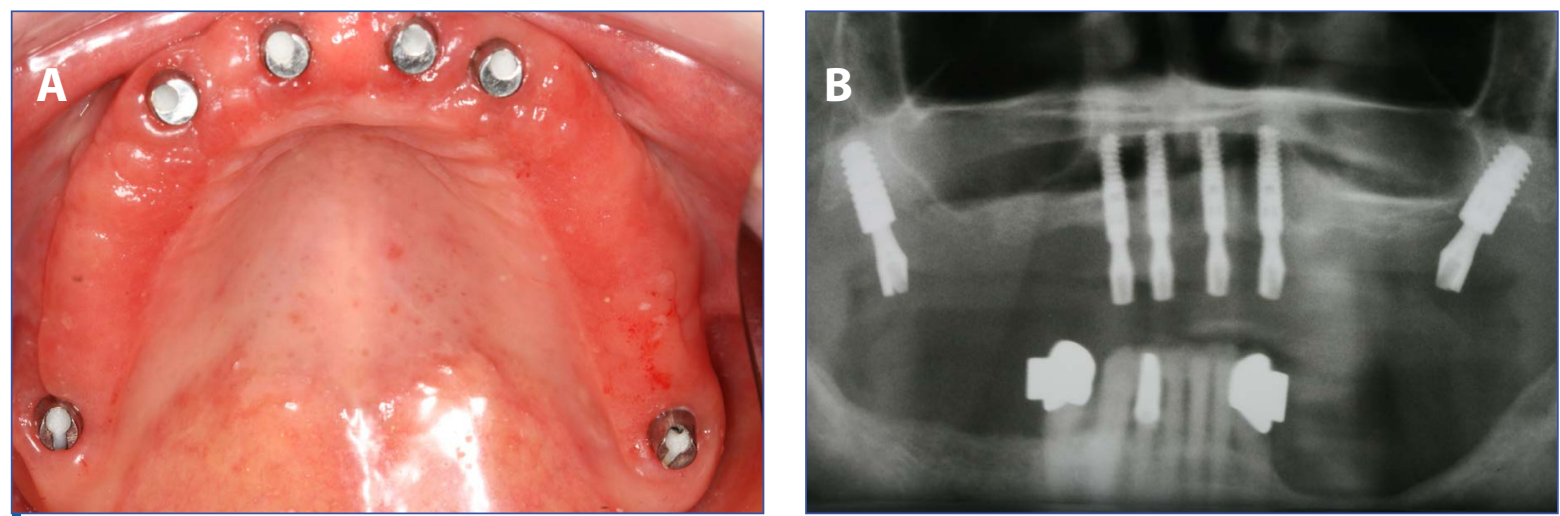

Figure 2. Clinical (A) and radiologic (B) conditions demonstrating the maxillary tuberosity providing support of tuberosity-embedded implants 10 years after functional loading of a removable implant-supported prosthesis.
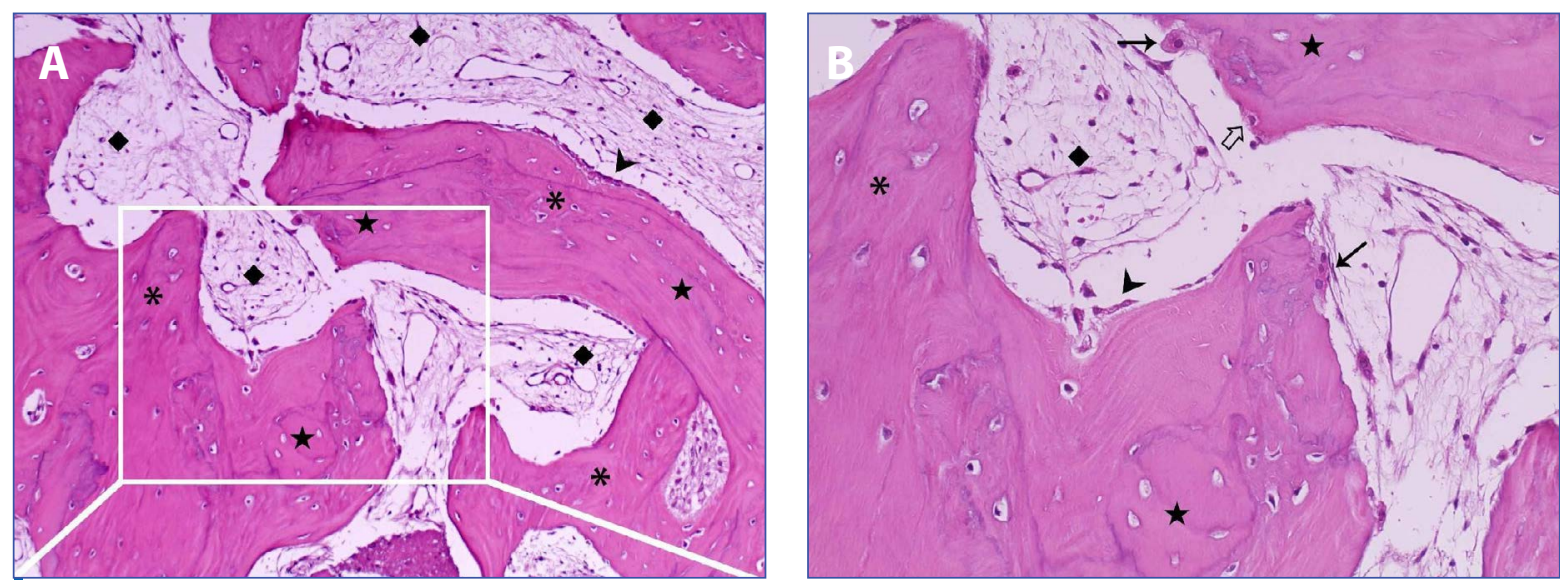

Figure 3. Representative photomicrographs of a biopsy specimens visualized by hematoxylin and eosin staining retrieved 3-months after grafting of maxillary tuberosity bone to the alveolar ridge. (A) Panoramic view (microscopic objective 10x) of well-vascularized and cell-rich marrow ( $\downarrow$ ), newly formed trabecular bone $\left(^{*}\right)$ with bone lining and/or osteoblast-like cells $(\boldsymbol{\nabla})$, and areas of non-vital bone $(\star)$ with empty lacunae. A large number of exuberant osteocytes in lacunae are associated with non-lamellar arrangement typical of newly remodeled bone. (B) At higher magnification (microscopic objective 20x), details of marrow ( $\bullet$ ), newly formed trabecular bone $(*)$, bone-lining cells or osteoblast-like cells $(>)$, osteoblasts ( $(\nabla)$, and osteoclasts $(\rightarrow)$ resorbing non-vital bone are evident. No signs of inflammatory reaction were observed.

thought to increase risk of bone resorption and implant failure, but more current studies have shown that angulated implants offer the same, if not better, long-term results when compared to their non-angulated counterparts - especially with implant lengths exceeding $13 \mathrm{~mm}$, regardless of angulation [25-27].

This may likely be due to greater primary stability imparted by the additional threads of longer implants, leading to more successful long-term outcomes.

This primary stability may have been a more critical factor to implant success than the spongy bone's lesser density support. Additional considerations for implant placement in the MT include the amount of bone available and bone height issues. As the MT is predominately lower density bone, the insufficiency of the bone tissue may inhibit a patient's candidacy for placement as ample bone volume is required for lasting results.

\subsection{Implants in the Tuber Region}

Pre-operative planning, implant design, superb osteotomy preparation using an optimal drilling procedure, and bone condensation are important factors to take into account in order to achieve long-term implant success. Detailed planning and bone ma- pping is advised on a per-patient basis to avoid surgical complications. Bone volume should be evaluated through the utilization of cone beam computed tomography (CBCT), but a combination of typical panoramic and periapical radiographs can provide adequate pre-operative bone information to substitute when CBCT is unavailable [28]. It has been suggested that a lateral window in the maxillary sinus can be made to further verify correct placement [18]. Once these considerations are taken into account, it is advised to choose a location more palatal as bone resorption is most commonly observed in the palatal direction, and distances of $35 \mathrm{~mm}$ or greater from opposing dentition are recommended to allow for surgical access [14]. More confined openings may negatively influence implant angulation or the ability for the surgeon to manipulate instruments. The use of a radiopaque marker integrated on a surgical guide or other acrylic guide can be employed along the edentulous ridge to assist in proper implant site location [12]. Several operatory procedures for implant placement in the MT have been suggested with mutual attributes yielding very similar results, and several studies have suggested that the utilization of an adapted drilling technique in sites of poor bone 

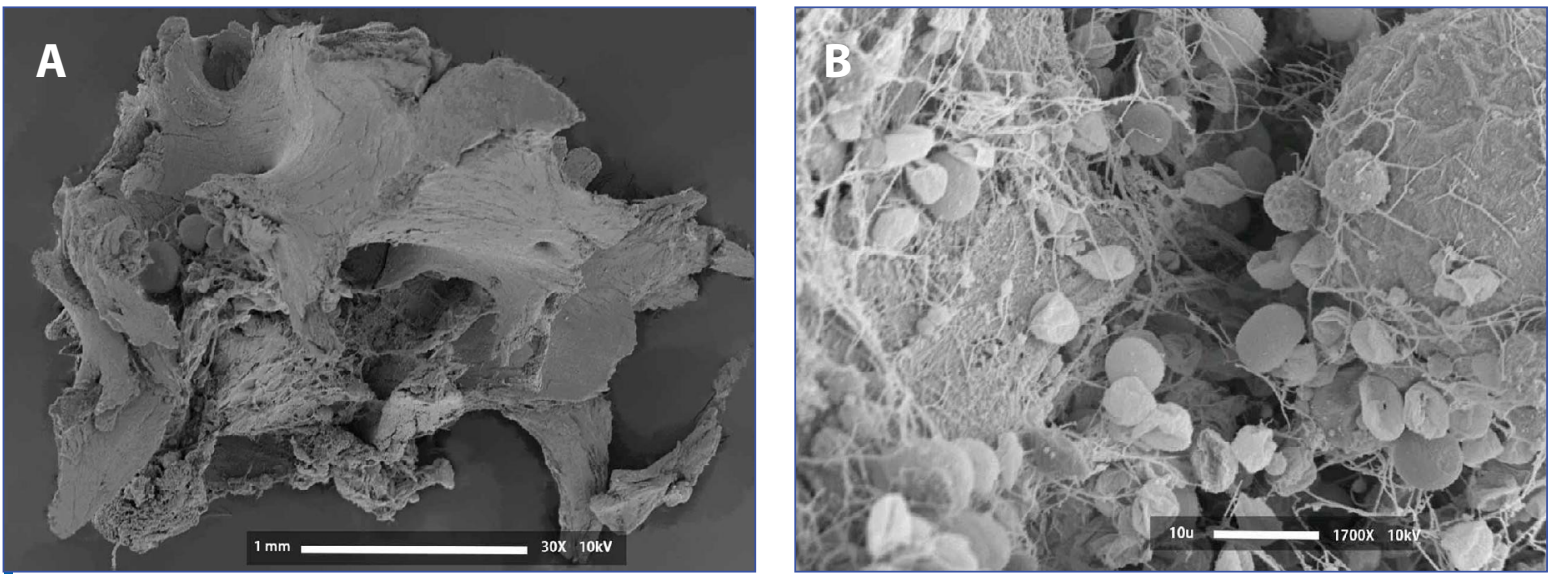

Figure 4. Representative scanning electron micrographs of a bony fragment retrieved from the maxillary tuberosity with associated particulate harvested via rongeur forcep. (A) Panoramic view of a particle with structure larger than $1 \mathrm{~mm}$ to facilitate the osseoconduction process (30x). (B) At higher magnification, details of bone matrix and fibrin network within cells are observed, which remain intact even after the particulate procedure $(1,700 x)$.

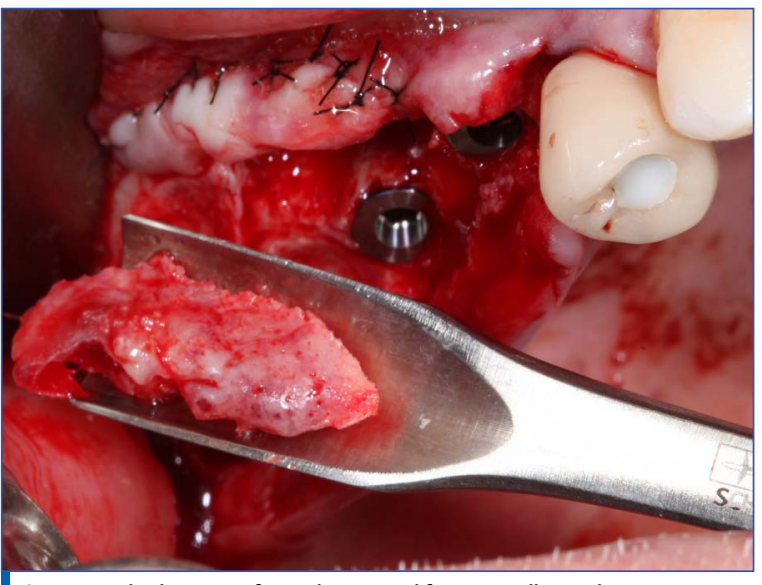

Figure 5. The bone graft was harvested from maxillary tuberosity in close proximity to the receptor site using IDR chisels. The graft was reshaped in relation to the defect configuration, and the remaining bone was crushed for use as particulate graft.

density is vastly advantageous in improving initial endosseous stability $[9,14,15,25,28-33]$. The highest success rates and greatest primary stability were observed after procedures that extensively employed under-sizing of the osteotomy, local bone condensation, osseodensification (Versah drills), or a combination of these methods as compared to that of traditional bone drilling techniques. By first under-drilling the bone with minimal countersinking and then mini-mizing the site preparation, the implant can obtain a constricted fit into the osteotomy once the fixture is eventually placed. This allows for a stronger thread engagement into the surrounding bone walls. Additionally, angulation of the implant site is critical, as the implant should maintain a $10-20^{\circ}$ mesial slant to mimic the natural angulation of the third molar $[12,34]$. A special emphasis is also placed on the bone condensation of the low quality bone. Bone condensation is obligatory in areas of reduced bone density in the posterior maxilla to attain sufficient implant stability [35]. To accomplish this condensation properly, an osteotome or modified osteotome technique or the method of osseodensification should be implemented over a conventional drilling tech- nique $[15,31,36]$. Blunt surgical osteotomes are recommended as the lack of sharpened edges, such as those found on drills, reduces the chance of cutting palatine and other maxillary arteries and nerves [15]. After bone condensation, significantly higher implant stability has been recorded immediately after surgery, as well as during the following observation periods compared to solely bone drilling techniques [33]. Procedures with the highest success rates and greatest implant stabilities consistently placed tapered implants in bone once implant sites were drilled and condensed [12-21]. The soft tissues of the maxillary tuberosity should be treated with care during surgery to avoid periosteal tears that will hinder proper blood flow and slow the healing process, and intimate wound approximation is required for optimal results. Complications at this site are minimal as bthere are no major vital structures in the immediate surgical area. Excess soft tissue over the surgical site should be trimmed to be no more than $3 \mathrm{~mm}$, allowing for adequate space for proper hygiene once the initial wound has healed [12]. Any implants placed in the tuber region should be allowed to heal for 6 months or more without loading in most cases. Premature loading would cause unwarranted stress on the surrounding low-density bone, increasing risk of failure before proper osseointegration [37]. In cases of severely weakened bone, progressive or early moderate loading protocols of the bone with implant prostheses may be used to strengthen the bone over the healing period $[38,39]$. Posterior occlusal forces can reach nearly ten times that of those in the anterior jaw, and these forces must be eliminated or adjusted to reach the desired load [12]. Loading forces can be decreased through the reduction of prosthesis occlusive contacts or through the adjustment of opposing dentition in contact with the prosthesis.

Shorter healing times (4-6 months) and more prompt integration may be plausible with implant surface modification [40]. Upon adequate healing of the implant site, fixed permanent prostheses can be fabricated and placed in a similar fashion as fixed dentures 

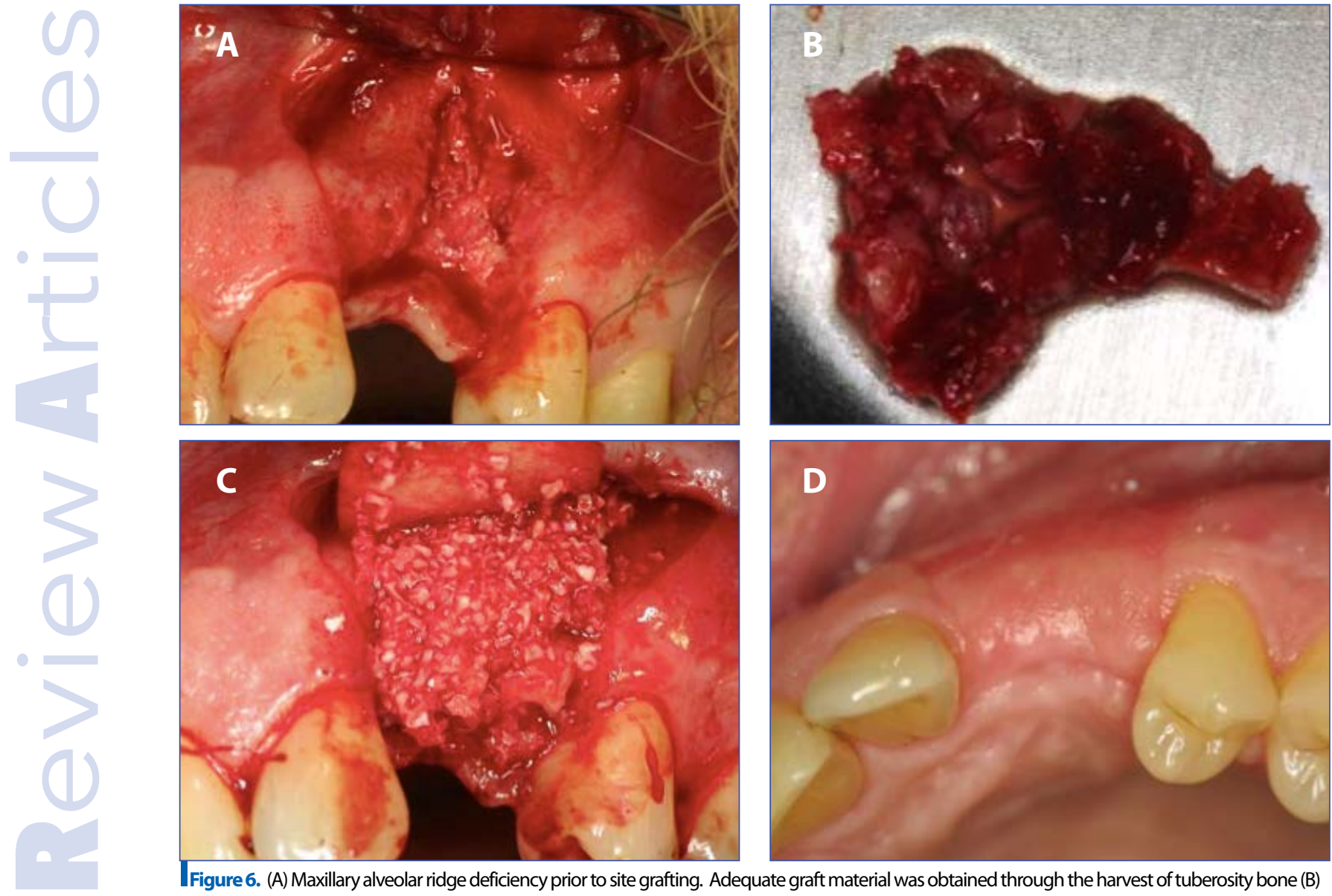

Figure 6. (A) Maxillary alveolar ridge deficiency prior to site grafting. Adequate graft material was obtained through the harvest of tuberosity bone (B) in combination with bovine osseous particulate as a composite graft (C). (D) The surgical site presented with excellent ridge contour after 3-months of healing post-operatively.

supported by implants placed in traditional maxillary positions. In fully or partially edentulous patients, posterior implants can be splinted together with anterior implants to reduce stresses in the supporting bone, as well as provide the framework for bridge or hybrid restorations that span larger proportions of the maxillary arch [41]. High survival rates of implants placed in the tuber region have been consistently shown in multiple studies [12-21,28]. Across these studies, 161 implants were placed in the maxillary tuberosity with a $95.03 \%$ survival rate over an average follow-up period of 52.08 months (Table 1). All studies demonstrated high success rates. Comparatively, 161 implants were placed in traditional regions in the maxilla with a $94.41 \%$ survival rate in the same patients over the same time interval (Table 1). Survival rates of implants in the MT and that of other maxillary implants were not significantly different from one another $(p>0.05)$. Marginal bone resorption across all studies was analogous to that of conventional implants placed throughout the maxilla despite different surgical modalities [28]. Similarities in survival rates amongst implants placed throughout the maxilla suggest tuberosity-based implants can provide a stable and predictable alternative to the traditional major rafting procedures that would other wise be required to stabilize implants in maxillary areas with bone deficiencies further anterior to the tuberosity. This provides a much more con- servative option for patients restricted financially or by medical conditions that hinder or delay healing processes. Survival rates over longer time intervals ( $>15$ years) are required to further validate this conclusion as an effective conservative alternative to major grafting or lifting procedures and to make accurate comparisons to established long-term studies of fixed prostheses. Often times, the bone volume of the maxillary tuberosity alone is insufficient for implant fixture placement. In these cases, implants have also been placed into the pterygoid plate area to overcome anatomical constraints similar to the way implants in the MT have been used in partially or completely edentulous patients [10,42-46]. The consideration of pterygoid implants was first proposed as a means of anchoring the posterior ends of fixed prostheses into as dense bone as possible in the posterior maxilla with implants longer than $15 \mathrm{~mm}$ [42]. This involves drilling through the pterygoid processes of the sphenoid, the pyramidal process of the palatine bone, as well within the MT in close proximity to the posterior wall of the sinus at approximately $35-55^{\circ}$ angulation [10]. The occlusal forces generated in the posterior maxilla far exceed those generated in anterior areas, and the bone quality of the MT is often inadequate to support fixed prostheses alone [12]. In these situations, compensation by means of fixture engagement of the pyramidal process of the cortical plate and associated pterygomaxillary 

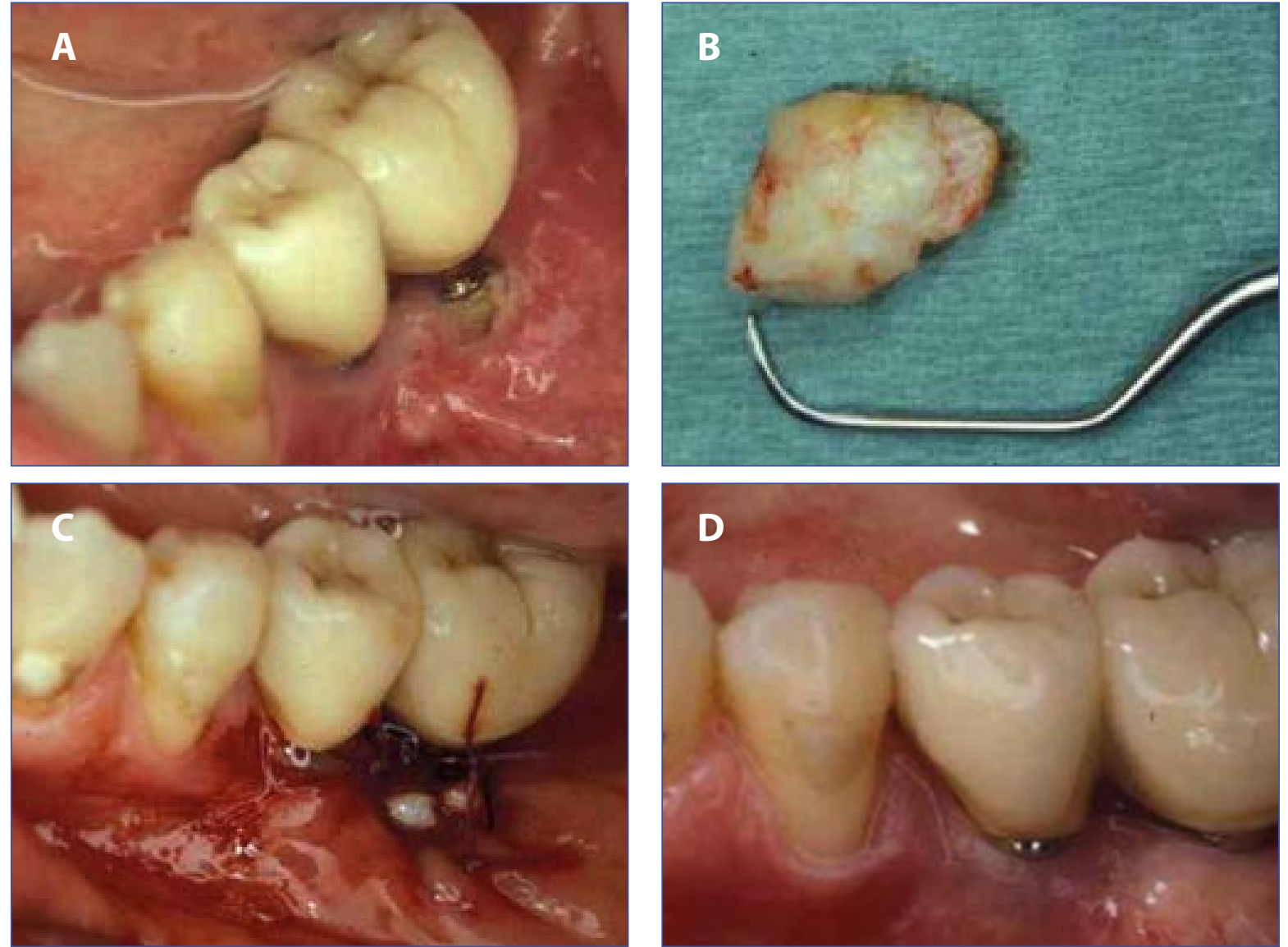

Figure 7. Peri-implant dehiscence (A) before placement of a soft tissue graft harvested from the maxillary tuberosity (B). The graft was immobilized within a pouch (C), and healing at the 2-years surgery demonstrated an outstanding soft tissue condition (D).

regions may be required [44]. Increased implant length in the pterygomaxillary region was found to lead to superior rates of osseointegration [46]. This may be a result of better implant apex engagement of the cortical bone between the medial and lateral pterygoid plates, thereby increasing stability after placement. It is important to note that although pterygoid implants utilize parts of the MT, not all MT-implants engage the area encompassing the pterygoid region. In this way, pterygoid implants and the implant restorations associated with them most frequently involve or incorporate a combination or direct connection of the pterygoid with the MT. Dental implants incorporating the pterygoid plate and accompanying areas have been shown to have high cumulative survival rates in edentulous maxillary arches ranging from $88.2 \%$ to $97.7 \%$ with similar expected bone loss as conventional implants in reported studies [10,47-50]. Implant placement into the pterygoid region poses similar difficulties as tuberosity implants: high operator learning curves, limited surgical access, and high risk of complication if arteries or their major branches are disrupted $[49,51]$. Regardless of inclusion of pterygoid engagement, these posterior maxillary implants function to support distal ends of fixed prostheses to alleviate bending and cantilever forces, as well as to provide overall denture stability. Their usage to restore missing dentition is highly viable as both a standalone procedure or in situations where they are combined with implants in the MT that serve to decrease nonaxial loads of permanent restorations.

\subsection{Bone Grafting and Harvesting from the Tuberosity}

Loss of osseous tissue from trauma, infection, or genetic resorption leads to low bone density that cannot support implants, and consequently, implantsupported restorations. Traditionally, intraoral sites of autogenous bone block grafts, such as the symphysis and ramus have been used to supplement alveolar ridges with deficiencies prior to implant placement [6]. Although the tuberosity serves as a candidate for direct implant fixation, when bone volume is abundant, this maxillary region can be manipulated with the use of various instruments to serve as an additional bone harvesting site to alleviate these deficiencies in cases of subpar bone mass for implant support. This is particularly critical as the MT frequently fails to be recognized as a bone graft source during implantation assessment. Typical CBCT scans and panoramic imaging can provide enough pre-operative assessment of the MT to determine if bone volume is appropriate for grafting $[5,52]$. Removal of bone from the MT is the least invasive alternative for intraoral grafting and would not require any extensive repair at the donor site while providing more than adequate bone volume to be used anteriorly to correct ridge deficiencies. This site has become a strong candidate as a grafting source in Immediate Dentoalveolar Restoration (IDR) of compromised sockets, 
where the cortico-cancellous graft can be shaped to the size of the distant defect and inserted to bolster bone mass [4,53]. Amongst autogenous bone sources, the greatest vertical gains are frequently seen from MT blocks compared to composite grafts in localized bone deficiencies $[7,54,55]$. The biological properties of a patient's own bone are enhanced when used as a grafting material, as the autogenous bone contains a wealth of bone marrow with great potential for angiogenesis (Figs. 3, 4). Autogenous bone is the optimal choice in larger block grafts due to its osseoinductive and osteogenic properties compared to that of xenografts, allogeneic, or alloplastic (synthetic) options [6,56-58]. Bone harvested from the MT (Fig. 5) can also be combined with other grafting materials to form composite grafts. In situations where only minimal amounts of hard tissue can be harvested from the MT, biomaterials may be used to supplement (Fig. 6). Bone substitutes, when embedded in osteoprogenitor cells of the MT, provide adequate bone formation in vivo [59]. Employment of composite grafts using biomaterials and autogenous tuber bone expands patient candidacy by reducing the total amount of patient bone required for grafting procedures, while still retaining the benefits of utilizing autogenous tissue. In this respect, the hard tissue of the MT can be manipulated in a plethora of ways to overcome the problems of bone deficiency throughout the maxilla. Different surgical alternatives for bone augmentation in post-extraction compromised sockets have been described [60]. However, some of these techniques require longer periods for rehabilitation and are usually expensive [61]. The Immediate Dento-alveolar Restoration (IDR), a one-stage technique, allows dental extraction, implantation, and provisionalization to occur in the same procedure as the flapless bone reconstruction using cortico-cancellous bone graft harvested from the maxillary tuberosity [62]. The IDR technique, aside from presenting lower overall costs and treatment time, has been shown clinically and radiographically to be effective with respect to soft and hard tissue stability in compromised sockets [63]. The advantages of IDR include: ease of tuberosity harvest, the malleability of bone fragment which allows adequate adaptation to the receptor region, and the biological membranous properties of the cortico-cancellous graft that promote effective bone and gingival healing. Furthermore, the trabecular nature of grafts harvested from the maxillary tuberosity contribute to increase revascularization capacity and to release growth factors to the receptor site [64]. Bone density at the buccal, palatal, and basal cortical maxillary tuberosity is less compared to other maxillary and mandibular bone locations. Due to the decreased thickness of its cortical bone, maxillary tuberosity grafts are easily shaped, yet its cortical structure can act as a biological barrier stabilizing the soft tissue and particulate bone graft around the implant
[65]. The total porosity and porous volume of these grafts indicate that the cortico-cancellous structure can act as a scaffold structure for cellular and vascular growth. Additionally, the maxillary tuberosity is a source of osteoprogenitor cells and growth factors [66]. Taken together, the cortical and cancellous bone from the maxillary tuberosity can be considered as an ideal structure for bone regeneration, as it is a natural scaffold filled with osteoblastic cells and growth factors [67].

\subsection{Soft Tissue Grafting and Harvesting from the Tuber Region}

The palatal area most commonly serves as the primary donor site for soft tissue grafts in cases of root coverage. This is not always the case with patients with diminished size, thickness, or rate of blood flow of the greater palatal artery which can lead to limited quantities of connective tissue available for harvest. The MT has been associated with connective tissue that can be used as an autogenous graft for soft tissue augmentation around implants (Fig. 7) simultaneously or secondarily with implant placement [4]. The gingival cuff of the MT has been shown as an excellent source of soft tissue to provide full, lasting coverage in more anterior regions of both the maxilla and mandible [3]. Transplantation of tuberosity connective tissue onto the aesthetic anterior gingival cuff demonstrated an improvement of the tissue biotype over a healing period to match the surrounding gingival tissue in texture and color [3]. Additionally, soft tissue grafting from the MT has been shown to be easier than grafting from the palatal masticatory mucosa $[3,68]$. Subepithelial connective tissue can simply be harvested from the MT and sutured within a pouch in areas of localized gingival recession with little to no complications to treat buccal soft tissue dehiscence around single implants [69-70].

This can fully or partially alleviate aesthetic exposure of implant threads due to bone loss around the fixture. Soft tissues of the MT can be employed throughout the oral cavity in a similar way as other traditional gingival grafts with similar success rates.

\section{Conclusions}

There are high success rates of dental implants placed in the MT, which can provide a stable and predictable alternative to the traditional major grafting procedures required to stabilize implants in bonedeficient maxillary areas anterior to the tuberosity. Proper placement of implants in this region with the correct surgical techniques, especially local bone condensing, can provide support of the prostheses in patients without complex grafting procedures. Bone and soft tissue harvested from the maxillary tuberosity provides many advantages and serves as an outstanding reservoir of tissue with excellent regeneration capacity. 


\section{Author Contributions}

NM and GR: wrote and edited the manuscript. JMR and LAP: provided the information about the Immediate Dento-alveolar Restoration (IDR) and supported with photographic documentation.

\section{References}

1. Lekholm U, Zarb GA. Patient selection and preparation. In: Brånemark PI, Zarb GA, Albrektsson T, eds. Tissue-integrated Prostheses: Osseointegration in Clinical Dentistry. Chicago, IL: Quintessence Publishing Co.; 1985:199-209.

2. Lekholm U, Gunne J, Henry $P$, et al. Survival of the Brånemark implant in partially edentulous jaws: a 10-year prospective multicenter study. Int J Oral Maxillofac Implants. 1999;14(5):639-645.

[PubMed] Google Scholar Scopus

3. Jung UW, Um YJ, Choi SH. Histologic observation of soft tissue acquired from maxillary tuberosity area for root coverage. J Periodontol. 2008;79(5):934-940. [Full text links] [CrossRef] [PubMed] Google Scholar Scopus

4. da Rosa JC, Rosa AC, Fadanelli MA, Sotto-Maior BS. Immediate implant placement, reconstruction of compromised sockets, and repair of gingival recession with a triple graft from the maxillary tuberosity: A variation of the immediate dentoalveolar restoration technique. J Prosth Dent. 2014;112(4):717-722.

[Full text links] [CrossRef] [PubMed] Google Scholar Scopus

5. Singh S. Management of infrabony defects in mandibular molars in a patient with generalized aggressive periodontitis using autogenous bone graft from maxillary tuberosity. $J$ Indian Soc Periodontol. 2010;14(1):53-56.

[Full text links] [CrossRef] [PubMed] Google Scholar

6. Tolstunov L. Maxillary tuberosity block bone graft: innovative technique and case report. J Oral Maxillofac Surg. 2009;67(8):1723-1729.

[Full text links] [CrossRef] [PubMed] Google Scholar Scopus

7. Jensen J, Simonsen EK, Sindet-Pedersen S. Reconstruction of the severely resorbed maxilla with bone grafting and osseointegrated implants: a preliminary report. J Oral Maxillofac Surg. 1990;48(1):27-32; discussion 33.

[Full text links] [CrossRef] [PubMed] Google Scholar Scopus

8. Jaffin RA, Berman $\mathrm{CL}$. The excessive loss of Brånemark fixtures in type IV bone: a 5-year analysis. J Periodontol. $1991 ; 62(1): 2-4$.

[Full text links] [CrossRef] [PubMed] Google Scholar Scopus

9. Krogh PH. Anatomic and surgical considerations in the use of osseointegrated implants in the posterior maxilla. Oral Maxillofac Surg Clin North Am. 1991;3(4):853-868.

10. Candel E, Peñarrocha $D$, and Peñarrocha $M$. Rehabilitation of the atrophic posterior maxilla with pterygoid implants: A Review. J Oral Implantol. 2012;38 Spec No:461-466.

[Full text links] [CrossRef] [PubMed] Google Scholar Scopus

11. Goiato MC, dos Santos DM, Santiago JF Jr, et al. Longevity of dental implants in type IV bone: a systematic review. Int J Oral Maxillofac Surg. 2014;43(9):1108-1116.

[Full text links] [CrossRef] [PubMed] Google Scholar Scopus

12. Bahat O. Osseointegrated implants in the maxillary tuberosity: report on 45 consecutive patients. Int J Oral Maxillofac Implants. 1992;7(4):459-467.

[CrossRef] [PubMed] Google Scholar Scopus

13. Krämer $A$, Weber $H$, Benzing U. Implant and prosthetic treatment of the edentulous maxilla using a bar-supported prosthesis. Int J Oral Maxillofac Implants. 1992;7(2):251-255. [CrossRef] [PubMed] Google Scholar Scopus

14. Venturelli A. A modified surgical protocol for placing implants in the maxillary tuberosity: clinical results at 36 months after loading with fixed partial dentures. Int J Oral Maxillofac Implants. 1996;11(6):743-749. [PubMed] Google Scholar Scopus

15. Nocini PF, Albanese M, Fior A, De Santis D. Implant placement in the maxillary tuberosity: the Summers' technique performed with modified osteotomes. Clin Oral Implants Res. 2000;11(3):273-278.

[Full text links] [CrossRef] [PubMed] Google Scholar Scopus

16. Markt JC. Implant prosthodontic rehabilitation of a patient with nevoid basal cell carcinoma syndrome: a clinical report. J Prosthet Dent. 2003;89(5):436-442.

[Full text links] [CrossRef] [PubMed] Google Scholar Scopus

\section{Acknowledgments}

There is no conflict of interest.
17. Alves CC, Neves M. Tapered implants: from indications to advantages. Int $J$ Periodontics Restorative Dent 2009;29(2):161-167.

[PubMed] Google Scholar Scopus

18. Ridell A, Gröndahl K, Sennerby L. Placement of Brånemark implants in the maxillary tuber region: anatomical considerations, surgical technique and long-term results. Clin Oral Implants Res. 2009;20(1):94-98.

[Full text links] [CrossRef] [PubMed] Google Scholar Scopus

19. Leles CR, Leles JL, de Paula Souza C, et al. Implant-supported obturator overdenture for extensive maxillary resection patient: a clinical report. J Prosthodont. 2010;19(3):240-244. [Full text links] [CrossRef] [PubMed] Google Scholar Scopus

20. Park YJ, Cho SA. Retrospective chart analysis on survival rate of fixtures installed at the tuberosity bone for cases with missing unilateral upper molars: a study of 7 cases. $J$ Oral Maxillofac Surg. 2010;68(6):1338-1344

[Full text links] [CrossRef] [PubMed] Google Scholar Scopus

21. Shirota T, Shimodaira O, Matsui Y, et al. Zygoma implantsupported prosthetic rehabilitation of a patient with a maxillary defect.Int JOralMaxillofac Surg. 2011;40(1):113-117. [Full text links] [CrossRef] [PubMed] Google Scholar Scopus

22. Khayat $P$, Nader $N$. The use of osseointegrated implants in the maxillary tuberosity. Pract Periodontics Aesthet Dent 1994;6(4):53-61; quiz 62 Google Scholar Scopus

23. Park HS, Lee YJ, Jeong SH, Kwon TG. Density of the alveolar and basal bones of the maxilla and the mandible. Am Orthod Dentofacial Orthop. 2008;133(1):30-37.

[Full text links] [CrossRef] [PubMed] Google Scholar Scopus

24. Yamaura T, Abe S, Tamatsu Y, et al. Anatomical study of the maxillary tuberosity in Japanese men. Bull Tokyo Dent Coll. 1998;39(4):287-292.

[PubMed] Google Scholar Scopus

25. Mattsson T, Köndell PA, Gynther GW, et al Implant treatment without bone grafting in severely resorbed edentulous maxillae. J Oral Maxillofac Surg. 1999;57(3):281-287.

[Full text links] [CrossRef] [PubMed] Google Scholar Scopus

26. Krekmanov L. Placement of posterior mandibular and maxillary implants in patients with severe bone deficiency: a clinical report of procedure. Int J Oral Maxillofac Implants. 2000:15(5):722-730.

[PubMed] Google Scholar Scopus

27. Aparicio C, Perales $P$, Rangert B. Tilted implants as an alternative to maxillary sinus grafting: a clinical, radiologic, and periotest study. Clin Implant Dent Relat Res. 2001;3(1):3949.

[Full text links] [CrossRef] [PubMed] Google Scholar Scopus

28. Lopes LF, da Silva VF, Santiago JF Jr, et al. Placement of dental implants in the maxillary tuberosity: a systematic review. Int. J Oral Maxillofac Surg. 2015;44(2):229-238.

[Full text links] [CrossRef] [PubMed] Google Scholar Scopus

29. Balshi TJ. Single, tuberosity-osseointegrated implant support for a tissue-integrated prosthesis. Int J Periodontics Restorative Dent. 1992;12(5):345-357.

[PubMed] Google Scholar Scopus

30. Alghamdi H, Anand PS, Anil S. Undersized implant site preparation to enhance primary implant stability in poor bone density: a prospective clinical study. J Oral Maxillofac Surg. 2001;69(12):e506-e512.

[Full text links] [CrossRef] [PubMed] Google Scholar Scopus

31. Blanco J, Suárez J, Novio $S$, et al. Histomorphometric assessment in human cadavers of the peri-implant bone density in maxillary tuberosity following implant placement using osteotome and conventional techniques. Clin Oral Implants Res. 2008;19(5):505-510.

[Full text links] [CrossRef] [PubMed] Google Scholar Scopus

32. Tabassum A, Meijer GJ, Wolke JG, Jansen JA. Influence of the surgical technique and surface roughness on the primary stability of an implant in artificial bone with a density equivalent to maxillary bone: a laboratory study. Clin Oral 
Implants Res. 2009;20(4):327-332.

[Full text links] [CrossRef] [PubMed] Google Scholar Scopus

33. Ahn SJ, Leesungbok R, Lee SW, et al. Differences in implant stability associated with various methods of preparation of the implant bed: an in vitro study. J Prosthet Dent. 2012;107(6):366-372.

[Full text links] [PubMed] Google Scholar Scopus

34. de Faria Almeida DA, Pellizzer EP, Verri FR, et al. Influence of tapered and external hexagon connections on bone stresses around tilted dental implants: three-dimensional finite element method with statistical analysis. J Periodontol. 2014;85(2):261-269.

[Full text links] [CrossRef] [PubMed] Google Scholar Scopus

35. Marković A, Ćalsan D, Čolić S, et al. Implant stability in posterior maxilla: bone-condensing versus bone-drilling: a clinical study. Oral Surg Oral Med Oral Pathol Oral Radiol Endod. 2011;112(5):557-563.

[Full text links] [CrossRef] [PubMed] Google Scholar Scopus

36. Huwais S, Meyer EG. A novel osseous densification approach in implant osteotomy preparation to increase biomechanical primary stability, bone mineral density, and bone-to-implant contact. Int J Oral Maxillofac Implants. 2017;32(1):27-36. [Full text links] [CrossRef] [PubMed] Google Scholar Scopus

37. Ekfeldt A, Christiansson U, Eriksson T, et al. A retrospective analysis of factors associated with multiple implant failures in maxillae. Clin Oral Implants Res. 2001;12(5):462-467.

[Full text links] [CrossRef] [PubMed] Google Scholar Scopus

38. Misch CE. Progressive loading of bone with implant prostheses. J Dent Symp. 1993;1:50-53.

[CrossRef] Google Scholar Scopus

39. Romanos GE, Grizas E, Laukart E, Nentwig GH. Effects of early moderate loading on implant stability: a retrospective investigation of 634 implants with platform switching and morse-tapered connections. Clin Implant Dent Relat Res. 2016;18(2):301-309.

[Full text links] [CrossRef] [PubMed] Google Scholar Scopus

40. Albrektsson $\mathrm{T}$, Brånemark $\mathrm{PI}$, Hansson $\mathrm{HA}$, Lindström J. Osseointegrated titanium implants. Requirements for ensuring a long-lasting, direct bone-to-implant anchorage in man. Acta Orthop Scand. 1981;52(2):155-170.

[CrossRef] [PubMed] Google Scholar Scopus

41. Bal BT, Cağlar A, Aydin C, et al. Finite element analysis of stress distribution with splinted and nonsplinted maxillary anterior fixed prostheses supported by zirconia or titanium implants. Int J Oral Maxillofac Implants. 2013;28(1):e27-e38. [CrossRef] Google Scholar Scopus

42. Tulasne JF. Osseointegrated fixtures in the pterygoid region In:Worthington P, Brånemark PI, eds. Advanced Osseointegration Surgery. Applications in the Maxillofacial Region. Chicago, IL: Quintessence Publishing Co Ltd; 1992: 182-188.

43. Graves SL. The pterygoid plate implant: a solution for restoring the posterior maxilla. Int J Periodontics Restorative Dent. 1994;14(6):512-523.

[PubMed] Google Scholar Scopus

44. Lee SP, Paik KS, Kim MK. Anatomical study of the pyramidal process of the palatine bone in relation to implant placement in the posterior maxilla. J Oral Rehabil. 2001;28(2):125-132. [Full text links] [CrossRef] [PubMed] Google Scholar Scopus

45. Rodríguez X, Méndez V, Vela X, Segalà M. Modified surgical protocol for placing implants in the pterygomaxillary region: clinical and radiologic study of 454 implants. Int J Oral Maxillofac Implants. 2012;27(6):1547-1553. [PubMed] Google Scholar Scopus

46. Balshi TJ, Wolfinger GJ, Slauch RW, Balshi SF. Brånemark system implant lengths in the pterygomaxillary region: a retrospective comparison. Implant Dent. 2013;22(6):610-612. [Full text links] [CrossRef] [PubMed] Google Scholar Scopus

47. Balshi TJ, Wolfinger GJ, Balshi SF 2nd. Analysis of 356 pterygomaxillary implants in edentulous arches for fixed prosthesis anchorage. Int J Oral Maxillofac Implants. 1999;14(3):398-406

[PubMed] Google Scholar Scopus

48. Vrielinck L, Politis C, Schepers S, et al. Image-based planning and clinical validation of zygoma and pterygoid implant placement in patients with severe bone atrophy using customized drill guides. Preliminary results from a prospective clinical follow-up study. Int J Oral Maxillofac Surg. 2003;32(1):7-14. [Full text links] [PubMed] Google Scholar Scopus

49. Curi MM, Cardoso $\mathrm{CL}$, Ribeiro Kde C. Retrospective study of pterygoid implants in the atrophic posterior maxilla: implant and prosthesis survival rates up to 3 years. Int J Oral Maxillofac Implants. 2015;30(2):378-383.

[Full text links] [CrossRef] [PubMed] Google Scholar Scopus
50. Bidra AS, Huynh-Ba G. Implants in the pterygoid region: a systematic review of the literature. Int J Oral Maxillofac Surg. 2011;40(8):773-781.

[Full text links] [CrossRef] [PubMed] Google Scholar Scopus

51. Lombardo G, Pardo A Mascellaro A et al Rehabilitation of severely resorbed maxillae with zygomatic implants: a literature review. Stoma Edu J. 2015;2(1):69-78.

52. Murakami I, Murakami Y, Kopp CD, et al. Panoramic implant notation system--a method to denote implant positions and prosthodontic modalities. J Prosthodont Res. 2012;56(1):65-69. [Full text links] [CrossRef] [PubMed] Google Scholar Scopus

53. da Rosa JC, Rosa AC, da Rosa DM, Zardo CM. Immediate Dentoalveolar Restoration of compromised sockets: a novel technique. Eur J Esthet Dent. 2013;8(3):432-443.

[Full text links] [CrossRef] [PubMed] Google Scholar Scopus

54. Gross BD, James RB, Fister J. Use of pocket inlay grafts and tuberoplasty in maxillary prosthetic construction. J Prosthet Dent. 1980;43(6):649-653.

[Full text links] [CrossRef] [PubMed] Google Scholar Scopus

55. Khojasteh A, Behnia H, Shayesteh YS, et al. Localized bone augmentation with cortical bone blocks tented over different particulate bone substitutes: a retrospective study. Int J Oral Maxillofac Implants. 2012;27(6):1481-1493. [PubMed] Google Scholar Scopus

56. KellerEE, van Roekel NB, Desjardins RP, Tolman DE Prosthetic surgical reconstruction of the severely resorbed maxilla with iliac bone grafting and tissue-integrated prostheses. Int $J$ Oral Maxillofac Implants. 1987;2(3):155-165.

[PubMed] Google Scholar

57. Kahnberg KE, Nilsson P, Rasmusson L. Le Fort I osteotomy with interpositional bone grafts and implants for rehabilitation of the severely resorbed maxilla: a 2-stage procedure. Int J Oral Maxillofac Implants. 1999;14(4):571-578.

[PubMed] Google Scholar Scopus

58. Simion M, Fontana F. Autogenous and xenogeneic bone grafts for the bone regeneration. A literature review. Minerva Stomatol. 2004;53(5):191-206. [PubMed] Google Scholar Scopus

59. Srouji $S$, Ben-David D, Funari $A$, et al. Evaluation of the osteoconductive potential of bone substitutes embedded with schneiderian membrane- or maxillary bone marrowderived osteoprogenitor cells. Clin Oral Implants Res. 2013:24(12):1288-1294.

[Full text links] [CrossRef] [PubMed] Google Scholar Scopus

60. Schneider D, Grunder U, Ender A, et al. Volume gain and stability of peri-implant tissue following bone and soft tissue augmentation: 1-year results from a prospective cohort study. Clin Oral Implants Res. 2011;22(1):28-37.

[Full text links] [CrossRef] [PubMed] Google Scholar Scopus

61. Buser D, Chappuis V, Bornstein MM, et al. Long-term stability of contour augmentation with early implant placement following single tooth extraction in the esthetic zone a prospective, cross-sectional study in 41 patients with a 5- to 9-year follow- up. J Periodontol. 2013;84(11):1517-1527. [Full text links] [CrossRef] [PubMed] Google Scholar Scopus

62. Rosa JC, Rosa AC, Rosa DM, Zardo CM. Immediate Dentoalveolar Restoration of compromised sockets: a novel technique. Eur J Esthet Dent. 2013;8(3):432-443.

[Full text links] [CrossRef] [PubMed] Google Scholar Scopus

63. Rosa JC, Rosa AC, Francischone CE, Sotto-Maior BS. Esthetic outcomes and tissue stability of implant placement in compromised sockets following immediate dentoalveolar restoration: results of a prospective case series at 58 months followup. Int J Periodontics Restorative Dent. 2014;34(2):199-208.

[Full text links] [CrossRef] [PubMed] Google Scholar Scopus

64. Rosa AC, da Rosa JC, Dias Pereira LA, et al. Guidelines for selecting the implant diameter during immediate implant placement of a fresh extraction socket: a case series. Int $J$ Periodontics Restorative Dent. 2016;36(3):401-407. [Full text links] [CrossRef] [PubMed] Google Scholar Scopus

65. da Rosa JC, Rosa AC, Fadanelli MA, Sotto-Maior BS. Immediate implant placement, reconstruction of compromised sockets, and repair of gingival recession with a triple graft from the maxillary tuberosity: a variation of the immediate dento-alveolar restoration technique. J Prosthet Dent. 2014; 112(4):717-722.

[CrossRef] Google Scholar

66. Cicconetti A, Sacchetti B, Bartoli A, et al. Human maxillary tuberosity and jaw periosteum as sources of osteoprogenitor cells for tissue engineering. Oral Surg Oral Med Oral Pathol Oral Radiol Endod. 2007; 104(5):618.e1-e12.

[Full text links] [CrossRef] [PubMed] Google Scholar Scopus

67. Rosa JC, Rosa AC, Francischone CE, Sotto-Maior BS. Esthetic outcomes and tissue stability of implant placement in 
compromised sockets following immediate dento-alveolar restoration: results of a prospective case series at 58 months follow-up. Int J Periodontics Restorative Dent. 2014;34(2):199-208. [CrossRef] Google Scholar

68. de Molon RS, de Avila ED, de Barros-Filho LA, et al. Reconstruction of the alveolar buccal bone plate in compromised fresh socket after immediate implant placement followed by immediate provisionalization. J Esthet Restor Dent. 2015;27(3):122-135.

[Full text links] [CrossRef] [PubMed] Google Scholar Scopus
69. Nizam N, Akcalı A. Vestibular unit transplantation in the coverage of gingival recession: a microsurgical approach. Int J Esthet Dent. 2014;9(4):516-524.

[PubMed] Google Scholar Scopus

70. Roccuzzo M, Gaudioso L, Bunino M, Dalmasso P. Surgical treatment of buccal soft tissue recessions around single implants: 1-year results from a prospective pilot study. Clin Oral Implants Res. 2014;25(6):641-646.

[Full text links] [CrossRef] [PubMed] Google Scholar Scopus

Nicholas MONTANARO

DDS

Department of Periodontology

School of Dental Medicine

Stony Brook University

Stony Brook, NY, USA

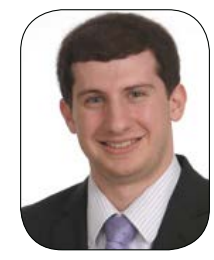

Nicholas Montanaro is an Oral and Maxillofacial Surgery resident within the Northwell Health System. He completed his undergraduate studies in Cell and Molecular Biology at the Hofstra University, Long Island, New York and later went on to earn his DDS degree from the Stony Brook University, Stony Brook, NY, USA. His current research focuses on the advancement of innovative dental implant technologies, development of regenerative biomaterials, and management of peri-implant disease.

\section{ouestions}

\section{Can maxillary tuberosity be used for implant placement?}

a. After panoramic radiographic evaluation?

ab. After occlusal radiograph?

ac. After CBCT?

$\square$ d. After periapical radiograph of the region?

\section{Tilted implants are associated with more failures and crestal bone loss:}

$\square$ a. The statement is not correct in case of supracrestal placement;

ab. The statement is not correct in case of subcrestal placement;

$\square c$. The statement is not correct in bruxers;

ad. The statement is not correct.

\section{An autogenous graft can be harvested from the}

口a. Tuberosity;

b. Chin region;

ac. Ramus;

$\square$ d. All of the above.

\section{Soft tissue augmentation as a free gingival graft from the tuberosity is recommended compared to the area of hard palate}

$\square$ a. For improvement of aesthetics;

b. To eliminate risks of bleeding;

ac. To increase thickness volume;

$\square$ d. All of the above. 